\title{
EFL at Greek Second Chance Schools: Examining the Learning Needs of Muslim Adult Learners
}

\author{
Eleni F. Kazantzi ${ }^{1} \&$ Makrina Zafiri ${ }^{1,2}$ \\ ${ }^{1}$ Department of English as a Foreign/International Language, School of Humanities, Hellenic Open University, \\ Patras, Greece \\ ${ }^{2}$ Foreign Language Office, Aristotle University of Thessaloniki, Greece \\ Correspondence: Makrina Zafiri, Foreign Language Office, Aristotle University of Thessaloniki, Greece.
}

Received: July 29, 2019

Accepted: August 23, 2019 Online Published: August 28, 2019

doi:10.5430/wjel.v9n2p74

URL: https://doi.org/10.5430/wjel.v9n2p74

\begin{abstract}
Discussions pertaining to minorities and their issues in education have recently been particularly heated in Greece, as changes which have occurred in Greece, Europe and at an international level, have triggered political and social turmoil and a reevaluation of cultural identities. The present paper attempts to contribute to this debate, concentrating on the Greek Muslim minority and their attempt to learn English as a foreign language (EFL) at Second Chance Schools (SCSs). The aim of this research is to explore Muslim individuals' learning needs in relation to EFL at SCSs, the reasons which prompt them to learn the foreign language, as well as the difficulties they encounter in their quest for this knowledge. Therefore, both quantitative and qualitative methods of data collection were applied to increase the credibility and validity of the results. In addition, the issue was examined through the perspective of both learners and adult educators in order to present a more comprehensive picture of the situation. The findings have shown that Muslim learners have associated the benefits of learning English with practical matters such as communicating while travelling abroad and enhancing their professional prospects. As for the learning obstacles they face, these pertain to typical issues in adult learning such as lack of time and fatigue, as well as their deficient knowledge of the Greek language, which can interfere with their learning. Finally, both learners and instructors agree that learning English at SCSs could be upgraded with more teaching hours per week and appropriate infrastructure.
\end{abstract}

Keywords: adult education, second chance school, EFL, minority learners, needs analysis

\section{Introduction}

The socio-political and economic changes in Europe created a need to bridge the cultural and social discrepancies amongst its citizens and secure their fundamental right to education. EU countries have placed great emphasis on educational policies promoting lifelong learning (European Commission, 2001). As a result, Second Chance Schools (SCSs) were founded in Greece (Law 2525/1997), to enable adults who have not completed their compulsory education to acquire knowledge and to develop skills which will enhance their accessibility to the labor market. Moreover, SCSs aim to help socially vulnerable groups to gain access to education and combat social exclusion (European Commission, 2001).

For the Greek Muslim minority, access to Greek-language education is a means of social advancement and personal development. Due to their diverse cultural background, however, their attendance at adult education structures is characterized by certain needs and difficulties. More specifically, the writers of the present paper have observed that they face particular difficulties in learning the English language. In searching for relevant research, one concludes that although there has been some interest on SCSs and their role in combating social exclusion, as well as SCS learners' attitudes towards learning English as a foreign language, there is little to no research focusing on minority learners' needs and difficulties pertaining to learning English at SCSs. However, there have been similar studies which served as a foundation for the present paper. More specifically, Nikolopoulou (2012) conducted research on SCSs as a means of educating socially vulnerable groups. Exakoustou (2016) dealt with Muslim women in Thrace and examined their reasons for interrupting compulsory education, as well as the reason or reasons which motivated them to attend adult education programs. Sansoglou (2016) investigated the learning needs of adults who attend SCSs, delving into the issue both from the learners' and the instructors' perspective. Finally, Sfagmenou (2016) examined SCS learners' views on EFL classes as a factor against social exclusion. 
This research investigates the learning needs of Muslim adult learners attending SCSs in relation to EFL, their reasons for learning English as a foreign language and the difficulties they face in their struggle to gain this knowledge. A fundamental aspiration of this research is that its findings will provide the necessary information to English language teachers and other SCS stakeholders to create a learning environment tailored to the needs of the Muslim minority. It is hoped that the key competencies and knowledge SCSs offer, in connection with the acquisition of a foreign language, can facilitate minority members to realize their full potential as active citizens.

The research questions which this study will attempt to answer are the following:

1. What are the learning needs of Greek Muslim learners in relation to English as a foreign language at Second Chance Schools?

2. What are their reasons for learning English?

3. Which are the difficulties they encounter when learning English as a foreign language in the course of their studies?

\section{Literature Review}

In order to appreciate the role of Muslim adult learners in the educational system, it was deemed necessary to set the theoretical background of the Greek Muslim minority, as well as the adult education context in Greece. This section discusses certain sociopolitical aspects of the Muslim minority, the concept of adult education and the teaching of English as a foreign language at SCS.

\subsection{The Greek Muslim Minority}

In social sciences, a minority does not necessarily refer to a group of people who are outnumbered by the majority in a social context. According to Wirth (1945, p.347), a minority is "a group of people who, because of their physical or cultural characteristics, are singled out from the others in the society in which they live for differential and unequal treatment, and who therefore regard themselves as objects of collective discrimination." Within the Muslim minority spectrum in Greece, we can identify three groups: Muslims of Turkish origin, Pomaks and Roma (Markou, 1997). Muslim minority members reside mainly in Western Thrace, while a small percentage lives on the Dodecanese islands (Rhodes \& Kos). The difference between the two communities lies in the educational opportunities offered to them. In short, the former (the Muslims of Western Thrace) have secured their educational rights in their mother tongue under the provisions of the Lausanne Treaty (1923), while the latter (the Muslims of the Dodecanese) are deprived of this privilege due to the historical developments of the time and are trapped in a situation which has been frozen in time.

The term used to describe the bilingual educational system legislated by the Lausanne Treaty, which is specifically designed for the Muslim minority of Western Thrace, is Minority Education (Tsitselikis \& Mavrommatis, 2003). Since its establishment, minority education has been a tipping point for Greek and Turkish policies, where each side attempted to exploit the situation and exercise politics (Liazos, 2007). Turkey used minority education as a means of dispersing national ideology through the promotion of their language and religion, while Greece aimed at eliminating the ethnic element of the minority group by defining religion as their sole connector (Panousi, 2007). Consequently, minority education has been influenced by institutional and political determinants, which entail an adverse effect on the instruction of both the Turkish and the Greek language.

\subsection{Adult Education}

According to Darkenwald and Merriam (1982, p.9), adult education is "a process whereby persons whose major social roles are characteristic of adult status undertake systematic and sustained learning activities for the purpose of bringing about changes in knowledge, attitudes, values, or skills." A well-known theory pertaining to adult learning is Knowles' Andragogy Model (1970), which underlines the differentiation of adult education in comparison to the education of minors. The theory of andragogy highlights the need to concentrate on learners' experiences and needs when teaching in an adult education context. The educational process must have a practical orientation and offer knowledge and skills which can be applied in real-life situations. Finally, instructors need to embrace their learners' different personalities, backgrounds and learning styles to achieve the best results.

The motivation that underlies adult learners' choice to participate in educational programs often depends on their socio-economic status. Nesbit (2005) posits that adult learners belonging to lower socio-economic groups are usually involved in work-related programs focusing on increasing human capital. On the other hand, learners coming from higher socio-economic strata seek programs relating to social recognition and self-realization (Zarifis, 2014). As for the difficulties which adults encounter in education, Kokkos (2007) contends that these difficulties pertain mainly to students' social obligations and responsibilities, as well as internal barriers which arise from a negative disposition, 
which they may have, towards education. Muslim adult learners are further burdened by their inadequate knowledge of the Greek language and the economic and social hardships which prevent them from committing to an educational program (Tsiakalos, 1999).

\subsection{Learning English at SCSs}

The teaching of English could not be absent from the SCS program, as it is considered a global language predominating in many fields such as technology, business and tourism. The SCS curriculum introduced by the Greek Ministry of Education in 2000 (FEK 943/31.7.2000) states that English was chosen as a means of communication among people of different nationalities and as a prerequisite for the autonomous and efficient performance of EU citizens in the professional and social spheres. More specifically, the EFL curriculum is based on five principles:

1. The analysis of learners' needs and interests is a necessary practice which should take place at the beginning of every school year.

2. The curriculum is adapted to learners' needs and interests arising from needs analysis.

3. Previous learning experiences must be taken into account when designing a lesson/course.

4. The curriculum is flexible and instructors can use it as a guide in deciding what to teach and how/when to teach it.

5. Remedial tuition to learners who cannot meet the course requirements and supplementary tutoring to advanced learners is decided upon in each SCS (Mitsikopoulou \& Sakelliou, 2006, p.16).

The EFL syllabus at SCSs is decided upon by the teacher and reflects the principles of the respective curriculum. There is no provision for predefined textbooks and instructors create their own teaching materials. The thematic areas are decided upon in cooperation with the learners, who are also encouraged to use their own learning materials. As far as content topic categories are concerned, the curriculum suggests that the thematic areas should reflect learners' needs and the selected texts should be directly related to students' everyday lives and interests.

\section{Methodology}

It was considered that the subject of the current paper could be studied more effectively if both qualitative and quantitative data were collected. The combination of qualitative and quantitative methods serve the purpose of triangulation, namely the use of different data collection methods and techniques, which enable a more thorough examination of an issue (Karalis, 2013). Quantitative analysis provides the possibility of a conditional generalization of the findings gathered from the sample of the general population (Karalis, 2013). It pertains to specific and measurable characteristics revealing general trends and an overall representation of the situation. On the other hand, the collection of qualitative data allows for a deep and multidimensional consideration of the subject matter (Richards, 2003). In this study, the qualitative data were complementary in the sense that they offered a deeper insight into both the instructors' and the learners' views.

\subsection{Participant Characteristics}

The target population of the study is Muslim learners attending SCSs. Therefore, the researchers selected all the SCSs operating in areas (prefectures) with the highest percentage of Muslim minority members. This is a case of nonprobability purposive sampling, where the researchers select individuals who have specific qualities and meet certain criteria (Etikan, Musa, \& Alkassim, 2016). The participants are the Muslim learners and EFL instructors of the SCSs of Komotini, Sapes, Xanthi (including the departments of Kentavros \& Mantaina) and Rhodes. The department of Myki (belonging to the SCS of Xanthi) was not included, because no English lessons were conducted at the time, due to the absence of an EFL instructor. In addition, although there is a Muslim community on the island of Kos, no SCS is in operation in that specific area.

\subsection{The Research Tools}

The research tools which were considered more appropriate for this research were the questionnaires and the semi-structured interviews. Two separate original questionnaires were designed, one intended for the instructors and one for the learners, as well as two separate sets of questions for the semi-structured interviews. They were constructed both in English and in Greek and the respondents chose the language of their preference.

Questionnaires are economically produced and administered in a short period of time, while respondents complete them anonymously, enabling the unbiased expression of their beliefs (Creswell, 2015). The questionnaires of this study include closed-ended questions which are dichotomous, multiple-choice, rating-scales and checklists. 
Open-ended questions are also included to elicit a range of replies which were not provided initially (Burgess, 2001). In semi-structured interviews, the interviewer prepares a framework of themes s/he wants to cover. The interview procedure is open and the questions are tailored to each context (Edwards \& Holland, 2013). The research tools were constructed after an overview of the relevant literature to determine the topics which needed to be covered and their design was also influenced by similar studies (Exakoustou, 2016; Karalis, 2013; Kordela, 2018; Tsaousi, 2012).

\subsubsection{The Questionnaire for the Learners}

The questionnaire begins with an introduction in which the aim of the research is explained and the anonymity of the data is highlighted. The first part relates to general information where respondents provide demographic data such as age, gender, marital status and the languages which they speak. The second part refers to the respondents' education, past experiences with school and attendance at the SCS. In the third part, respondents express their views, preferences and expectations on learning English, as a foreign language, at the SCSs. They are also asked about the difficulties they encounter in learning the language and their thoughts on how the situation could improve. Finally, respondents are asked whether they are willing to participate in the semi-structured interview. If they accept, they provide their telephone number so that the researchers can contact them.

\subsubsection{The Questionnaire for the Adult Educators}

The questionnaire for EFL instructors is divided into five parts. The first part pertains to general information such as age, gender, education, training and teaching experience. In the second part, they are asked about their learners' profile and their experience in working with Muslim learners at the SCS. The third part focuses on EFL and learners' interest in it. In the fourth part, instructors are asked about how they cope with their learners' needs and the difficulties which their students face when learning English. The fifth part pertains to lesson procedures such as the approaches, the methods, the techniques and the tools which they employ in the classroom. Instructors are also asked whether they are willing to participate in the semi-structured interview and whether they are willing to provide their phone number so that the researchers can contact them.

\subsubsection{The Semi-structured Interview for the Learners}

The semi-structured interview for learners consists of five parts. The first part pertains to personal information such as gender, age and the SCS class. The second part addresses the learners' decision to enroll at the SCS and what they expect from their studies. In the third part, respondents express their views on EFL, whether the lessons meet their needs and how they think they will benefit from them. The fourth part focuses on the difficulties which learners face in learning English with a particular emphasis on the parameter of bilingualism and classroom communication. Finally, the third part pertains to learning procedures, where respondents are given the opportunity to share their thoughts on how they think the English lesson could improve and become better adjusted to their needs.

\subsubsection{The Semi-structured Interview for the Adult Educators}

The semi-structured interview for the teachers consists of four parts. The first part pertains to the teachers' profile, namely their age, gender, educational background and teaching experience. The second part concerns their learners' profile. This includes age, gender, cultural background as well as how teachers cope with teaching in a culturally diverse environment. The third part refers to the needs, obstacles and benefits of learning English at SCSs. The last part revolves around procedures such as teaching approaches, methods and techniques, learning tools and materials, topics of interest and classroom interactions. Finally, teachers offer their opinions on how teaching English at SCSs could improve.

\subsection{Procedures}

Prior to conducting the research, the researchers came into contact with the General Secretariat for Lifelong Learning and received written permission to carry out the research at the aforementioned SCSs. Subsequently, the researchers contacted the school principals and the respective EFL teachers to make the necessary arrangements. Next, the research tools were pilot tested in order to identify potential problem areas (Cohen, Manion, \& Morrison, 2007). The draft questionnaires and semi-structured interviews were tested for effectiveness, clarity, coherence and completion time. The trial group of learners (two women and a man) chose to complete the questionnaire in Greek. Certain problems with clarity were detected, as learners encountered words and phrases, they were not familiar with. The researchers proceeded to replace these unfamiliar words and phrases with simpler vocabulary (synonyms mostly) and phrases with which students were familiar. The time for the completion of the questionnaire was estimated to last 15-20 minutes. There were no issues detected in the semi-structured interviews which were estimated to last 5-10 minutes.

The questionnaire for the teachers was pilot tested with two EFL instructors (both women), who found it satisfactory 
in terms of grammatical organization and overall coherence. Participants were also asked to express their opinion on whether they thought the questionnaire served the purpose of the research, to which they replied positively. The time needed to complete it was 7-10 minutes. No issues were encountered during the pilot testing of the interviews and their estimated time was 15-20 minutes.

All questionnaires were produced and distributed as hard copies. After communicating with the school-principals, arrangements were made for the researchers to visit the SCSs of Komotini, Xanthi, Kentavros (in which one of the two researchers works) and the department of Mantaina to distribute the questionnaires. The appointments were set at convenient times for the EFL instructors so as to discuss the procedure without obstructing the educational process. As for the SCS of Rhodes, after communicating with the principal and the EFL instructor, the researchers arranged to send the questionnaires by courier and received them back likewise.

Subsequently, the researchers contacted the learners and teachers who were willing to participate in the semi-structured interviews by phone to make arrangements. The interviews took place in the premises of each SCS and were conducted face to face, individually, after the researchers received permission from the principals of the aforementioned schools. The interviewees were informed on all the matters regarding the procedure to secure their permission and create a climate of trust (Seidman, 2006). The purpose and use of the given information were explained, the anonymity of the respondent was ensured and the use of a recording device was disclosed and justified. The interviews were recorded using a mobile telephone apparatus and were subsequently transcribed.

\subsection{Data Analysis}

The data gathered from the questionnaires for teachers and learners were analyzed using the Statistical Package for Social Sciences software (SPSS, version 23). The replies to the open questions were divided into categories and analyzed with the same software. The information collected with the semi-structured interviews was handled using thematic analysis, which is the process of identifying themes and patterns within the data (Braun \& Clark, 2006). Recordings were relistened and transcripts were reread various times in order to detect recurring themes, develop categories and index the data accordingly.

\section{Results}

This section presents the research results, as they arise from the questionnaires and semi-structured interviews. The research findings are divided into four sections corresponding to the four research tools.

\subsection{The Questionnaire for Learners}

For the quantitative part of the research pertaining to learners, 200 questionnaires were delivered to 6 SCSs of which 142 were completed. Due to the descriptive nature of the research questions, the data were analyzed through descriptive analysis (Loeb et al., 2017).

All 142 respondents stated that they speak Greek, while the vast majority also speak Turkish. Interestingly enough, $21.1 \%$ included English amongst the languages they speak. As for the language they use most in their everyday lives, $42.25 \%$ reported speaking Greek, followed by $35.92 \%$ who speak Turkish as their first language.

Table 1. Most Used Language at each SCS

\begin{tabular}{lcccccc}
\hline & Xanthi & Kentavros & Mantaina & Komotini & Sapes & Rhodes \\
\hline Greek & $51.1 \%$ & $19.4 \%$ & $0.0 \%$ & $51.6 \%$ & $35.7 \%$ & $100.0 \%$ \\
Turkish & $44.7 \%$ & $19.4 \%$ & $0.0 \%$ & $48.4 \%$ & $64.3 \%$ & $0.0 \%$ \\
Pomaki & $4.3 \%$ & $61.3 \%$ & $100.0 \%$ & $0.0 \%$ & $0.0 \%$ & $0.0 \%$ \\
\hline
\end{tabular}

Looking at the responses given for each SCS separately (Table 1), we see that Greek was selected as the language mostly spoken in urban areas, while it was selected by $100 \%$ of the respondents in Rhodes. Bilingual adults belonging to a minority group, typically choose the majority language in the workplace as well as most other daily activities and use the minority language in a more restricted range of contexts (Garraffa, Obregon, \& Sorace, 2017).

Only $21.8 \%$ of respondents reported speaking English before the SCS, of whom $48 \%$ learnt it while trying to help their children to study. What is interesting is that $92.3 \%$ expressed an affinity towards the English lessons at the SCS, while the vast majority stated that, compared to other lessons, they find their English lessons easy (30.3\%) or of moderate difficulty $(41.5 \%)$. 
Table 2. Motivation for Learning English

\begin{tabular}{llll}
\hline & Yes & No & Not Sure \\
\hline Find a job & $69.0 \%$ & $21.8 \%$ & $9.2 \%$ \\
Travel abroad & $66.9 \%$ & $26.8 \%$ & $6.3 \%$ \\
Improve at job & $66.2 \%$ & $19.0 \%$ & $14.8 \%$ \\
Use the Internet & $61.3 \%$ & $30.3 \%$ & $8.5 \%$ \\
Talk with foreigners & $53.5 \%$ & $41.5 \%$ & $4.9 \%$ \\
Help children & $52.8 \%$ & $38.0 \%$ & $9.2 \%$ \\
English films & $39.4 \%$ & $54.2 \%$ & $6.3 \%$ \\
English songs & $35.2 \%$ & $55.6 \%$ & $9.2 \%$ \\
English books & $26.8 \%$ & $66.9 \%$ & $6.3 \%$ \\
\hline
\end{tabular}

Regarding their motivation for learning English (Table 2), most respondents stated that it will help them find a job or improve work conditions in their workplace. Other popular options were travelling and using the Internet. Kordela's (2018) study examined adult learners' attitudes towards learning English and found that, regarding their reasons for learning the language, $85.7 \%$ of the respondents' replies related to travelling, while $69.6 \%$ stated that they need it for employment purposes.

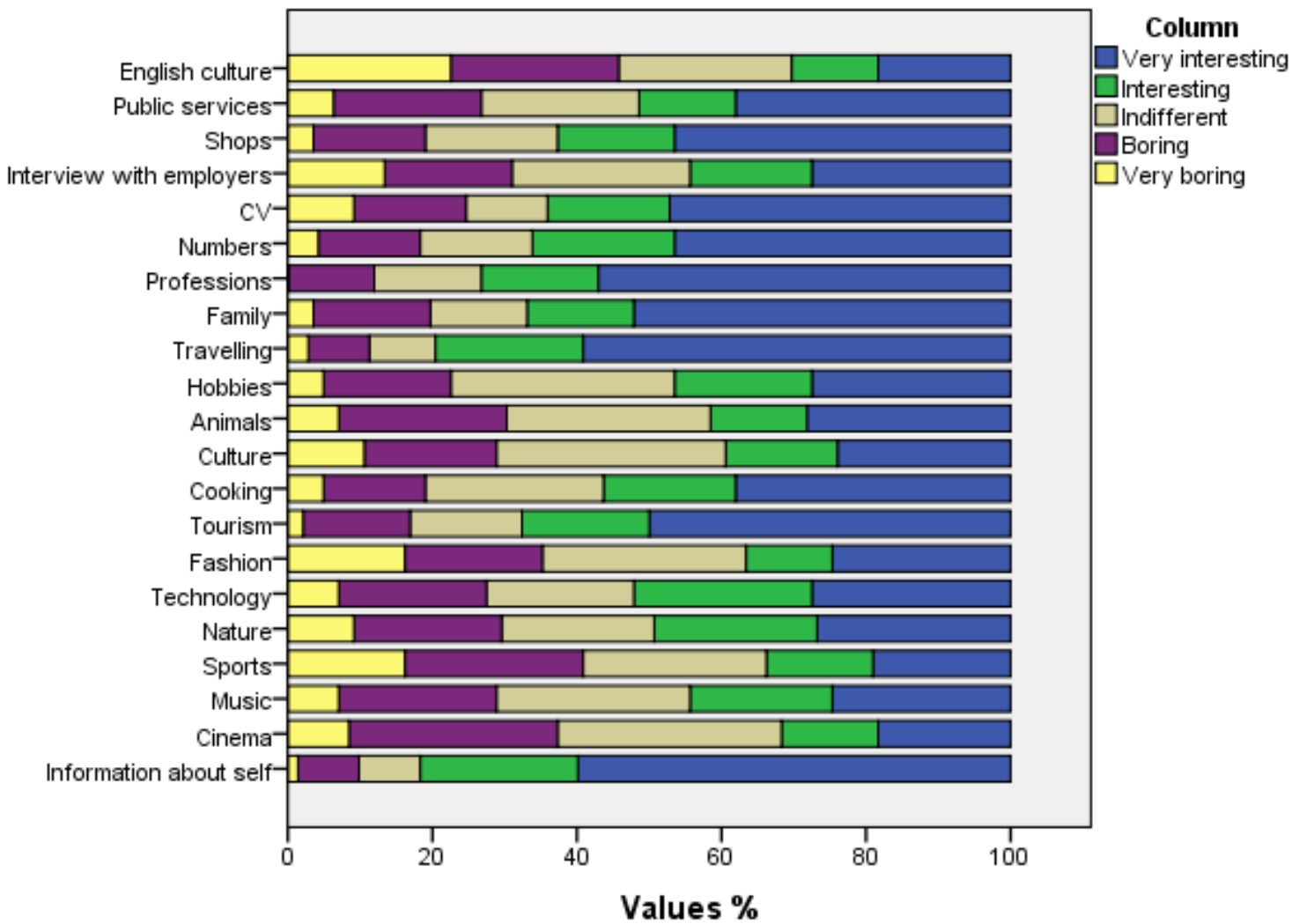

Figure 1. Learners' Preferences in Topics

Figure 1 illustrates the respondents' preferences towards certain topics. "Information about myself" is the most popular option as $81.7 \%$ found it very interesting or interesting, followed by travelling, professions, tourism and family. 
Table 3. Obstacles in Learning English

\begin{tabular}{llll}
\hline & Yes & No & Not sure \\
\hline Physical tiredness & $48.6 \%$ & $44.4 \%$ & $7.0 \%$ \\
Age & $35.9 \%$ & $56.3 \%$ & $7.7 \%$ \\
Failure anxiety & $35.2 \%$ & $52.8 \%$ & $12.0 \%$ \\
Personal problems & $31.0 \%$ & $57.0 \%$ & $12.0 \%$ \\
$\begin{array}{l}\text { Teacher does not encourage } \\
\text { participation }\end{array}$ & $15.5 \%$ & $70.4 \%$ & $14.1 \%$ \\
Lack of classroom cooperation & $17.6 \%$ & & \\
Social environment does not & $19.0 \%$ & $68.3 \%$ & $14.1 \%$ \\
encourage attendance & & $63.4 \%$ & $17.6 \%$ \\
Absent a lot & $21.1 \%$ & $59.0 \%$ & \\
Lack of confidence & $31.0 \%$ & $54.9 \%$ & $9.9 \%$ \\
Does not understand teacher talk & $35.9 \%$ & $52.8 \%$ & $14.1 \%$ \\
Lack of time & $45.8 \%$ & $42.3 \%$ & $11.3 \%$ \\
More interested in Greek rather & $38.7 \%$ & $50.7 \%$ & $10.6 \%$ \\
than English & & & \\
Embarrassment in classroom & $34.5 \%$ & $55.6 \%$ & $9.9 \%$ \\
Lessons not adjusted to learning & $19.7 \%$ & $59.2 \%$ & $21.1 \%$ \\
needs & & & \\
\hline
\end{tabular}

As already discussed in subsection 2.2, the difficulties adults encounter when participating in an educational program often relate to their obligations and responsibilities outside school (Kokkos, 2007). Table 3 shows that, in this study, the most prominent obstacles in learning English related to physical tiredness and lack of time, while learners also stated that they are more interested in learning Greek rather than English.

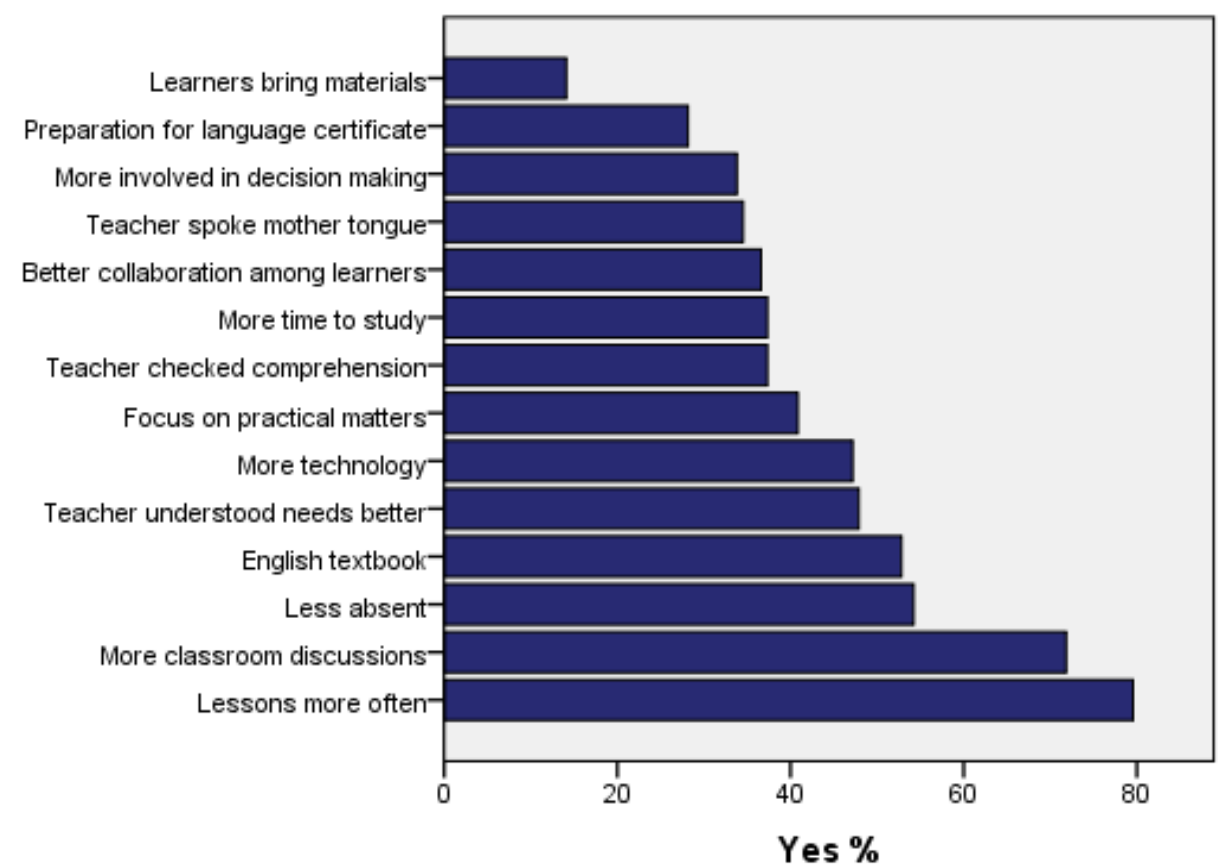

Figure 2. Ways to Learn English Better 
Regarding respondents' views on how learning English at the SCS could improve (Figure 2), having lessons more often was by far the most popular option, followed by more classroom discussions. Learners stated that being less absent would also help them, while a significant percentage considers the lack of English textbooks a disadvantage. Respondents are not keen on assuming an active role in the educational process, as being more involved in decision-making was the third least popular choice, while bringing their own materials was last. Doyle (2008) supports that learners hesitate to take responsibility for their own learning because they feel that this would make things harder for them.

\subsection{The Questionnaire for Adult Educators}

The questionnaire for adult educators was completed by six teachers in total. The data were managed through descriptive analysis. Due to the small number of participants, frequencies are presented through the number of occurrences rather than percentiles.

Table 4. Teachers' Ways of Examining Learners' Needs

\begin{tabular}{lcc}
\hline & N of responses & Percent of cases \\
\hline Conversation & 6 & $100.0 \%$ \\
Observation & 3 & $50.0 \%$ \\
Questionnaires & 2 & $33.3 \%$ \\
Tests & 0 & $0.0 \%$ \\
\hline
\end{tabular}

All respondents examined their learners' needs and the way in which they achieved this was mainly through conversation (Table 4). This is a common practice among SCS instructors, as the findings of Sansoglou's (2016) study showed that $95.8 \%$ of the teachers working at SCSs engage in learner needs analysis in their classrooms. Moreover, the majority of the teachers believe their education and training has adequately prepared them to meet their learners' needs, while two respondents answered that they were not sure.

Moving on to the lesson procedures which were followed by the teachers, five out of six teachers chose a balance between teacher-and learner-centeredness and only one of the teacher's lessons were purely learner-centered. The aforementioned is supported by the existing literature, as the merits of the learner-centered approach have been extensively discussed in Greece and abroad (Doyle, 2011; Lynch, 2010). However, there has also been research conducted suggesting that teacher-centered practices can prove beneficial in certain cases, such as teaching grammar (Zohrabi, Torabi, \& Baybourdiani, 2012).

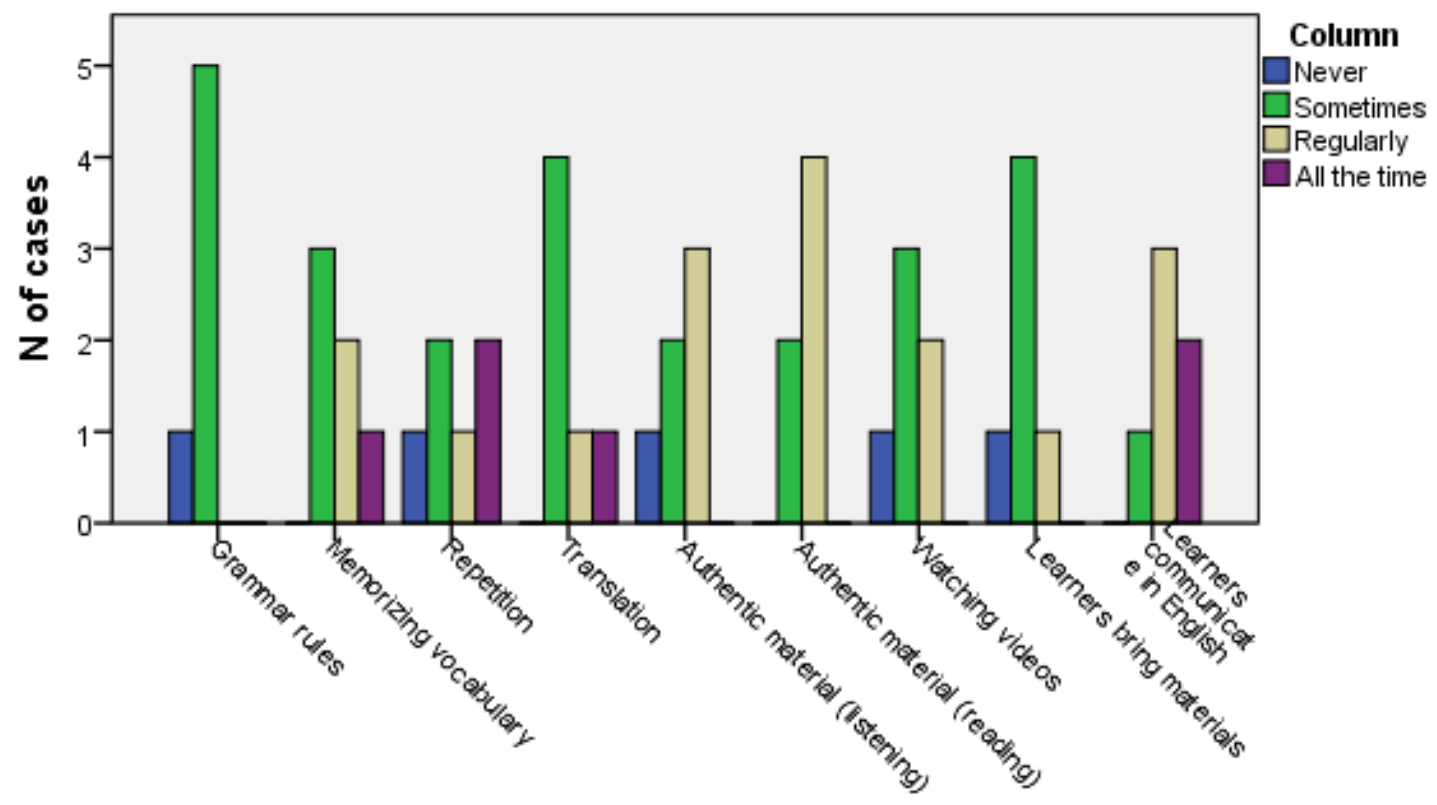

Figure 3. Teachers' Methods in Teaching English 
As shown in Figure 3, respondents also adopt a combination of practices deriving from different methods.

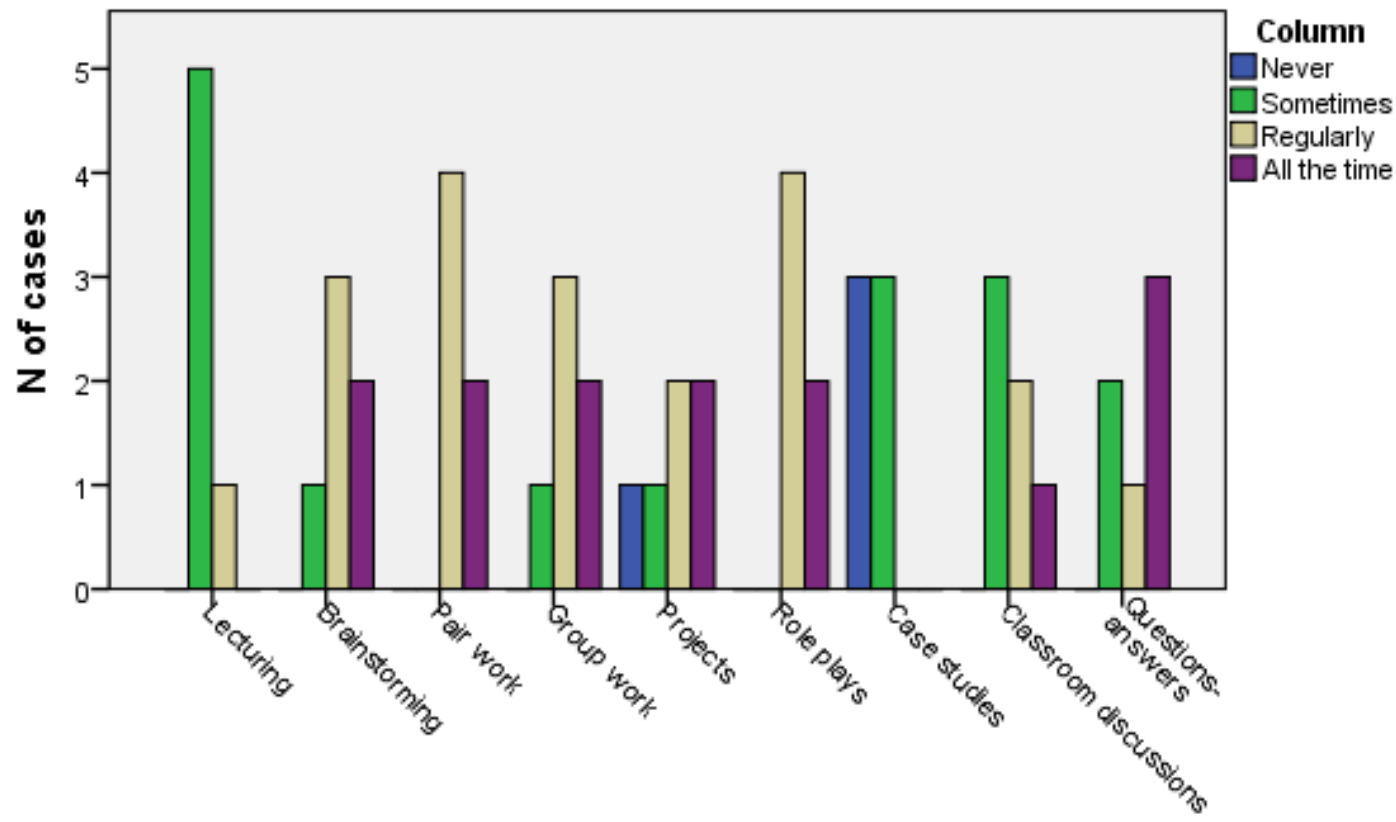

Figure 4. Teachers' Techniques in Teaching English

Figure 4 shows that teachers employ techniques which are considered both traditional (lecturing, questions-answers) and communicative (role-plays, pair work). This diversity in methods and techniques can prove particularly beneficial, as research shows that when teachers vary their delivery, students stay engaged with the subject matter and retain the content of a course in the long run (Doyle, 2011).

\subsection{The Semi-structured Interviews for Learners}

For the qualitative part of the research, nine students from three different SCSs agreed to take part in a semi-structured interview. All students chose to be interviewed in Greek rather than in English. Data were analyzed through thematic analysis. As the database created after the transcription of the interviews was relatively small and easy to handle, it was deemed best to analyze it by hand (Creswell, 2015).

Most learners reported having only limited prior experience with English, which was gained mostly through their children and the television. As for the benefits of learning English, being able to communicate when travelling was the most popular answer, while some learners referred to English as the language dominating every aspect of modern life. In a sense, respondents view English as a lingua franca or a global language, which Dörnyei and Ushioda (2009) claim can be a motivating factor, as learners may wish to be integrated into a global culture through learning English.

As regards the difficulties and obstacles learners face when learning English, most responses related to the skills of speaking and reading. Despite finding it difficult, most learners indicated speaking as one of their favorite skills and only one respondent expressed an interest in reading. These results are similar to Kordela's (2018) findings which indicate an inclination of adult learners towards speaking, while the difficulties they face relate mostly to speaking and listening. When asked if speaking two or three additional languages affects language learning, five learners responded that speaking Turkish actually helps in learning English because, compared to Greek, there are more similarities in the letters of the alphabet and in certain words.

When asked about their opinion on the classroom materials, five respondents addressed the lack of English textbooks in the SCS curriculum. According to Basturkmen (2010), students favor the use of textbooks because it provides them with a sense of security and gives them an overview of what they are expected to learn. The majority also expressed the need for technology-related learning tools (computers, videos, DVDs, tablets). When asked to suggest ways in which learning English at the SCS could improve, all learners expressed a desire for more teaching hours per week dedicated to EFL. This is in line with Sfagmenou's (2016) research, in which most respondents stated that more teaching hours dedicated to the English language would lead to better learning outcomes. 


\subsection{The Semi-structured Interviews for Adult Educators}

The semi-structured interviews for adult educators were conducted with the participation of four EFL teachers. The data were analyzed through thematic analysis and by hand, as above. When asked about their experience working with Muslim learners, apart from the cultural and communication issues which existed, teachers stated that they sometimes need to focus on the Greek language rather than the English language. Research has shown that improving their Greek language proficiency is a primary goal of Muslim learners enrolling at SCSs (Dimasi, Papastamatis, \& Stogios, 2014; Kaimaki, 2018; Tsaousi, 2012).

Regarding the obstacles learners face when learning English, they indicated factors such as lack of time, motivation and confidence while they also mentioned the learners' limited abilities in the Greek language and absence of prior contact with the English language. The views on whether the speaking of two or three additional languages affects learners' performance in English are varied. Some teachers stated that learners have already developed language learning strategies which facilitate the process. Others view the differences among the languages as a hindrance, while one teacher highlighted the fact that most learners have only a fragmented knowledge of each language, which does not offer a breeding ground for acquiring a new one. This divergence is also depicted in research which relates to bilingualism in the classroom. Paap and Greenberg (2013) found no significant cognitive advantage in bilingual individuals, while Dubrowska and Street (2006) suggest that bilingual minority speakers develop metalinguistic skills which enhance their L2 performance.

In addition, three teachers believe that having a different mother tongue from their learners only partially affects the learning process and may even facilitate it, as they are compelled to employ various communication strategies. Respondents also believe that learning English can help increase learners' confidence and constitute an incentive to further develop their skills after completing their SCS studies.

Finally, respondents believe that teaching English at SCSs could improve with more teaching hours per week and better infrastructure. The lack of educational equipment and infrastructure is an issue that has been addressed before by teachers working at SCSs in relevant research (Nikolopoulou, 2012). One teacher suggested the existence of a specially equipped classroom used solely for teaching English, while another mentioned the possibility of connecting the EFL lessons at the SCS with the attainment of a language certificate. The latter is also depicted in Sfagmenou's (2016) study, in which $87.9 \%$ of the respondents stated that the attainment of a certificate in English after their SCS studies would be useful in their professional life.

\section{Discussion and Implications}

The purpose of the present research was to examine the learning needs of Muslim adults attending SCSs and draw certain conclusions on how teaching English can be amended to achieve the best learning outcomes in the specific educational context. The discussion of the research findings and the proposed practical implications are based on the results which derive from all four data collection tools, similar studies, as well as the SCS philosophy and the EFL curriculum.

\subsection{What Are the Learning Needs of Greek Muslim Learners in Relation to English at Second Chance Schools?}

First of all, we will examine the results deriving from the participants' personal information. A fact requiring attention is that Turkish and Pomaki are the languages learners residing in rural areas mostly use, so instructors must remember that communication difficulties might be more intense in these regions. Moreover, only a fraction of the respondents had previous experience with learning English, so it is to be expected that in these contexts, English lessons will start at the beginner level.

As regards topics, the results of the present research (as well as other relevant research) show that three major themes arise, namely, personal information, practical everyday matters and tourism/travelling. The first two topics allude to adult learners' "life-centered" orientation to learning (Knowles, Holton, \& Swanson, 2015, p.46). Consequently, instructors have to ensure that the topics discussed in the classroom are of a practical nature and correspond to real-life situations. The third theme points to the multicultural dimension of language learning. Learners view English as a lingua franca, serving as a communication language among speakers of different cultural backgrounds (Cogo \& Dewey, 2012). Contrary to popular views on language learning, teaching English as a lingua franca encourages the use of learners' L1 to facilitate communication and understanding (Kiczkowiak \& Lowe, 2019).

Another noteworthy issue is the learners' desire for the use of an English textbook. Although textbooks do not always promote communicative learning or cater for learners' needs (Molvaersmyr, 2017), they provide a sense of security and offer an overview of what is to be learnt (Basturkmen, 2010). Consequently, after conducting the necessary needs analysis and in cooperation with their learners, instructors can gather appropriate materials and create a folder Published by Sciedu Press 
or corpus which will include a contents page, expected outcomes, etc. This will create the illusion of a textbook, providing learners with a point of reference for the course content.

Teachers employ a combination of traditional/teacher-centered and communicative/learner-centered practices depending on what they intend to teach, which can help their learners to achieve the best learning outcomes (Zohrabi, Torabi, \& Baybourdiani, 2012). However, this research depicts the learners' inclination towards a teacher-centered classroom in which they hold a more passive role. It is the instructor's responsibility, then, to help learners change their way of thinking about education and become active learners by shaping their own learning course (De la Sablonnière, Taylor, \& Sadykova, 2009). After all, one of the fundamentals of the SCS's philosophy is to turn students into life-long learners. When students are encouraged to work with others, to give and receive feedback, to express their ideas clearly and to find their own learning sources, they also gain life skills which will benefit them in the long run (Bishop, Caston, \& King, 2014).

\subsection{What Are Their Reasons for Learning English?}

Regarding the respondents' reasons for learning English at SCSs, professional development was one of the most popular options. This is to be expected as a basic knowledge of English is a prerequisite for many job openings. A first step would be to inform learners of the way in which learning English enhances their career prospects, as knowing the value of a language can be a motivating force to learn it (Lightbown \& Spada, 2006). Subsequently, EFL instructors can use resources such as job advertisements, videos of job interviews, curricula vitae, etc. to help SCS learners to come into contact with work-related English.

What would also be useful to this end is a suggestion made by one of the teachers during the interviews, namely, to connect the EFL lessons at the SCS with a language certificate. Relevant research has been conducted which shows that learners consider language certificates useful for the professional milieu (Sfagmenou, 2016). Moreover, the attainment of a language certificate has been found to be a strong motivating factor for language learning (Hovhannisyan, 2014). It provides a sense of achievement and enhances learners' confidence in their abilities. Of course, getting from beginner to B2 level (which is often the minimum level required for a job) within two years seems rather difficult considering the allocated hours per week for English. However, if learners succeed in passing the A1-A2 level English language exam, then this can be an incentive for them to set higher goals and continue learning English even after the completion of their SCS studies.

5.3 What are the Difficulties They Encounter When Learning English as a Foreign Language in the Course of Their Studies?

The results showed that the main difficulties which learners faced were physical tiredness, lack of time and the fact that they were more interested in learning Greek rather than English. The first two obstacles relate to factors which are intertwined with adult life as adults have various obligations and cannot dedicate the same time and energy to the learning process as children do. Consequently, EFL instructors must create a supportive environment for their learners and offer the appropriate flexibility to suit their circumstances and schedules (Falasca, 2011). The creation of a positive learning environment, where learners' needs and concerns are heard and discussed, facilitates their active involvement (Vella, 2002).

Learners seem to believe that it is more important to learn the Greek language better and do not consider learning English a priority. This could be interpreted as lack of intrinsic motivation. There has been research suggesting that intrinsic motivation stimulates spontaneous learning behavior and induces qualitatively better and more effective learning than extrinsic motivation (Ushioda, 2008). Therefore, the educational process must be driven by learners' personal goals, needs and interests. This entails involving them in making informed decisions regarding their own learning and fostering a sense of personal responsibility.

The findings showed that neither teachers nor learners view their differences in mother tongue and cultural background as an obstacle to learning. Nevertheless, it is the EFL instructor's responsibility to reinforce learners' cultural identity and find ways in which their cultural and linguistic profile can be used to their benefit (Magos, 2003). Carrasquillo and Rodriguez (2002) contend that it is of utmost importance to support learners' mother tongue at school so that the target language can evolve around it and to view their native language and culture as a facilitator rather than as a deficiency.

\section{Conclusion}

This paper demonstrated the adverse conditions which Muslim minority members have confronted in terms of their education and overall position within the Greek society. Inadequate minority education and social exclusion have prevented their personal and professional development. The purpose of the present research was to examine the learning Published by Sciedu Press 
needs of adult Muslim learners in relation to EFL at SCSs, the obstacles they encounter and their reasons for learning the language. The research findings can provide EFL instructors who are working with adult Muslim learners in SCSs, as well as other similar educational contexts, with valuable information which can be used to guide appropriate adjustments to the curriculum and the learning experiences they deliver. In this way, they can create a supportive learning environment, which will contribute to Muslim learners' personal fulfilment and professional development.

This study was conducted with the aspiration to make a small contribution to the field of adult education, focusing on the members of the Muslim minority. However, every research has its shortcomings, so certain limitations arose during the process. Although no particular issues were detected with the completion of the questionnaires, this was not the case with the semi-structured interviews. Learners were hesitant to participate in them and those who did remained rather reserved and gave mostly short replies, so the researchers were not able to elicit much information. Moreover, out of the nine interviewees, eight were women and only one was a man so the sample of the interviews is not representative of the target population. Finally, although the research was initially planned for earlier, organizational and procedural matters delayed the process, which eventually took place at a time which was not optimal as it coincided with Ramadan (Note 1). Consequently, many learners were absent from school and the number of participants was slightly smaller than expected, reducing the generalizability of the findings.

The scope of the current study was threefold: to examine adult Muslim learners' needs, reasons and difficulties in relation to learning EFL at SCSs. The analysis of the research data was descriptive, meaning that its purpose was to identify patterns within the target population. However, in order to acquire a deeper understanding of the three strands of the study, it would be useful to identify correlations between certain variables. Further research could be conducted on how factors such as age, gender, locality and previous education relate to Muslim learners' motivation, needs and learning obstacles, to make predictions on their future performance at SCSs. Subsequently, a study examining cause-effect relationships could be conducted. Causal research offers strong evidence on the effects of a certain teaching intervention on the learning outcomes of a specific population (Loeb et al., 2017). Overall, a combination of descriptive, correlation and causal research may provide useful information for the development of an educational environment, in which adult Muslim learners can thrive.

\section{References}

Basturkmen, H. (2010). Developing Courses in English for Specific Purposes. New York: Paglave Macmillan. https://doi.org/10.1057/9780230290518

Bishop, C. F., Caston, M. I., \& King, C. A. (2014). Learner-centered environments: Creating effective strategies based on student attitudes and faculty reflection. Journal of the Scholarship of Teaching and Learning, 14(3), 46-63. https://doi.org/10.14434/josotl.v14i3.5065

Braun, V., \& Clarke, V. (2006). Using thematic analysis in psychology. Qualitative Research in Psychology, 3(2), 77-101. https://doi.org/10.1191/1478088706qp063oa

Burgess, T. (2001). A general introduction to the design of questionnaires for survey research. Leeds: University of Leeds. Retrieved from https://nats-www.informatik.uni-hamburg.de/pub/User/InterculturalCommunication/top2.pdf

Carrasquillo, A. L., \& Rodriguez, V. (2002). Language Minority Students in the Mainstream Classroom. Bristol: Multilingual Matters. https://doi.org/10.21832/9781853595660

Cogo, A., \& Dewey, M. (2012). Analysing English as a Lingua Franca: A Corpus Driven Investigation. New York: Continuum International Publishing Group.

Cohen, L., Manion, L., \& Morrison, K. (2007). Research Methods in Education (6 ${ }^{\text {th }}$ ed.). London: Routledge. https://doi.org/10.4324/9780203029053

Creswell, J. W. (2015). Educational research: Planning, conducting, and evaluating quantitative and qualitative research (5th ed.). Boston, MA: Pearson.

Darkenwald, G. G., \& Merriam, S. B. (1982). Adult Education. Foundations of practice. New York: Harper and Row.

De la Sablonnière, R., Taylor, D. M., \& Sadykova, N. (2009). Challenges of applying a student-centered approach to learning in the context of education in Kyrgyzstan. International Journal of Educational Development, 29(6), 628-634. https://doi.org/10.1016/j.ijedudev.2009.01.001

Dimasi, M., Papastamatis, A., \& Stogios, I. (2014). Muslim Minority of Thrace: Educational concerns. Mare Ponticum, 4(4), 13-30.

Dörnyei, Z., \& Ushioda, E. (2009). Motivation, Language Identity and the L2 Self. Buffalo, NY: Multilingual 
Matters. https://doi.org/10.21832/9781847691293

Doyle, T. (2008). Helping Students Learn in a Learner-Centered Environment: A guide to facilitating learning in higher education. Sterling: Stylus Publishing, LLC.

Doyle, T. (2011). Learner-centered teaching: Putting the research on learning into practice. Sterling, VA: Stylus Publishing.

Dubrowska, E., \& Street, J. (2006). Individual differences in language attainment: comprehension of passive sentences by native and non-native English speakers. Lang. Sci. 28, 604-615. https://doi.org/10.1016/j.langsci.2005.11.014

Edwards, R., \& Holland, J. (2013). What is qualitative interviewing? London: Bloomsbury.

Etikan, I., Musa, S. A., \& Alkassim. R. S. (2016). Comparison of Convenience Sampling and Purposive Sampling. American Journal of Theoretical and Applied Statistics, 5(1), 1-4. https://doi.org/10.11648/j.ajtas.20160501.11

European Commission (2001). Second Chance Schools: The results of a European pilot project. Retrieved from: http://www.e2oespana.org/wp-content/uploads/2016/06/Report_E2C-Schools_pilot_project.pdf

Exakoustou, A. (2016). The Education of the Muslim Minority's Women of Thrace (Dissertation). Patras: Hellenic Open University. (Translation from Greek)

Falasca, M. (2011). Barriers to adult learning: Bridging the gap. Australian Journal of Adult Learning, 51(3), 583-590. https://files.eric.ed.gov/fulltext/EJ954482.pdf

Garraffa, M., Obregon, M., \& Sorace, A. (2017). Linguistic and Cognitive Effects of Bilingualism with Regional Minority Languages: A Study of Sardinian-Italian Adult Speakers. https://doi.org/10.3389/fpsyg.2017.01907

Government Gazette, Law 2525/1997 (FEK 188/23.9.1997). Integrated Lyceum, access of its graduates to Tertiary Education, evaluation of the educational work and other provisions. (In Greek). Retrieved from http://dide.flo.sch.gr/web/wp-content/uploads/2013/05/DIDEFlorinas_N_2525_1997_Me_Oles_Tis_Allages.pdf

Government Gazette, Ministerial Decree 943/2000 (FEK 943/31.7.2000). Second Chance School Curriculums. (Translation from Greek). Retrieved from http://www.et.gr/index.php/anazitisi-fek

Hovhannisyan, I. (2014). Learners' attitudes and motivation to learn English: English as a foreign or as an international language? (Doctoral thesis). Thessaloniki: Aristotle University of Thessaloniki.

Kaimaki, C. (2018, July 6). The SCS of Komotini gives a second chance in knowledge. (In Greek). Retrieved from https://www.paratiritis-news.gr/article/204392/Mia-deuteri-eukairia-sti-gnosi-dinei-to-SDE-Komotinis

Karalis, T. (2013). Motivation and barriers to the participation of adults in lifelong education. Athens: INE GSEE. (Translation from Greek).

Kiczkowiak, M., \& Lowe, R. J. (2019). Teaching English as a Lingua Franca: The Journey from EFL to ELF. Delta Publishing.

Knowles, M. S. (1970). The modern practice of adult education: Andragogy versus Pedagogy. New York: Association Press.

Knowles, M. S., Holton, E. F., \& Swanson, R. A. (2015). The adult learner: The definitive classic in adult education and human resource development (8th ed.). New York, NY: Routledge. https://doi.org/10.4324/9781315816951

Kokkos, A. (2007). Characteristics of Adult Learners and Conditions for Effective Learning Conditions. In Educational Material for Trainers of Theoretical Training (Volume I). Athens: EKEPIS. (Translation from Greek).

Kordela, C. (2018). A needs analysis approach to teaching English to adult learners. (Dissertation). Patras: Hellenic Open University.

Liazos, N. (2007). The Turkish textbooks of minority education in the development of intercultural relations between Christians and Muslims in Western Thrace (Doctoral thesis). Thessaloniki: AUTh. (Translation from Greek).

Lightbown, P. M., \& Spada, N. (2006). How languages are learned ( $3^{\text {rd }}$ ed.). Oxford: Oxford University Press.

Loeb, S., Dynarski, S., McFarland, D., Morris, P., Reardon, S., \& Reber, S. (2017). Descriptive Analysis in Education: A Guide for Researchers. National Center for Education Evaluation and Regional Assistance. Retrieved from https://files.eric.ed.gov/fulltext/ED573325.pdf

Lynch, D. N. (2010). Student-centered learning: The approach that better benefits students. Virginia Beach: Virginia 
Wesleyan University.

Magos, K. (2003). Educational techniques for learners from religious and cultural minorities. In Educational Material for SEK Trainers (Volume II). Athens: EKEPIS. (Translation from Greek)

Markou, G. (1997). Intercultural Education. Greek and International experience. Athens: KEDA. (Translation from Greek).

Mitsikopoulou, V., \& Sakelliou, E. (2006). Literacy in the English Language: Curriculum, methodological proposals, educational material for Second Chance Schools. Athens: GGEE-IDEKE. (Translation from Greek).

Molvaersmyr, T. (2017). Teachers' textbook use in English. (Thesis). Harstad: The Arctic University of Norway.

Nesbit, T. (2005). Social class and adult education. New Directions for Adult and Continuing Education, 2005(106), 5-14. https://doi.org/10.1002/ace.174

Nikolopoulou, M. (2012). Adult Education as a means of educating socially vulnerable groups: The case of Greek Second Chance Schools (Dissertation). Patras: Hellenic Open University.

Paap, K. R., \& Greenberg, Z. L. (2013). There is no coherent evidence for a bilingual advantage in executive processing. Cogn. Psychol. 66, 232-258. https://doi.org/10.1016/j.cogpsych.2012.12.002

Panousi, T. (2007). The obstacles that the Muslims of Western Thrace face when learning the Greek language at the KEK of Komotini (Dissertation). Patras: Hellenic Open University. (Translation from Greek)

Richards, K. (2003). Qualitative Inquiry in TESOL. Basingstoke: Palgrave Macmillan. https://doi.org/10.1057/9780230505056

Sansoglou, E. (2016). Investigating the educational needs of learners at Second Chance Schools: Educators' and learners' views (Dissertation). Patras: Hellenic Open University. (Translation from Greek).

Seidman, I. (2006). Interviewing as Qualitative Research: A Guide for Researchers in Education and the Social Sciences $\left(3^{\text {rd }}\right.$ ed.). New York: Teachers College Press.

Sfagmenou, E. (2016). The English Literacy at the Second Chance Schools as a factor against social exclusion (Dissertation). Patras: Hellenic Open University.

Treaty of Peace with Turkey signed at Lausanne, Brit. Emp., -Fr., -It., -Gr., -Rom., -Serb., -Croat., Slov., \& Turk., July 24, 1923. Retrieved from: https://wwi.lib.byu.edu/index.php/Treaty_of_Lausanne

Tsaousi, M. (2012). Muslim learners at the Second Chance School of Komotini. Is it a real second chance in effective education and overall development for the specific learners? (Dissertation). Patras: Hellenic Open University. (Translation from Greek).

Tsiakalos, G. (1999). Human dignity, social exclusion and education in Europe. In E. Spanou (Ed.), Human Dignity and Social Exclusion. Educational Policy in Europe. Athens: Ellinika Grammata. (Translation from Greek).

Tsitselikis, K., \& Mavrommatis, G. (2003). The Turkish language in education in Greece. Mercator-Education. Retrieved from

https://www.mercator-research.eu/fileadmin/mercator/documents/regional_dossiers/turkish_in_greece.pdf

Ushioda, E. (2008). Motivation and good language learners. In C. Griffiths (Ed.), Lessons from Good Language Learners (pp. 19-34). Cambridge: Cambridge University Press. https://doi.org/10.1017/CBO9780511497667.004

Vella, J. (2002). Learning to listen. Learning to teach. The power of dialogue in educating adults. San Francisco: Jossey-Bass Publishers.

Wirth, L. (1945). The Problem with Minority Groups. In Linton, R. (Ed.), The Science of Man in the World Crisis, (pp. 347-372). New York: Columbia University Press.

Zarifis, G. K. (2014). Continuing Education and Lifelong Learning: Theory and Practice (Professor's notes). Thessaloniki: AUTh. (Translation from Greek).

Zohrabi, M., Torabi, M. A., \& Baybourdiani, P. (2012). Teacher-centered and/or student-centered learning: English language in Iran. English Language and Literature Studies, 2(3), 18-30. https://doi.org/10.5539/ells.v2n3p18

Notes

Note 1. Ramadan is the most sacred month in the Islamic religion. During this month, Muslims abstain from pleasures and do not eat and drink from morning to sunset, to achieve complete physical and spiritual cleansing. 